\title{
'We're a rich city with poor people': municipal strategies of new-build gentrification in Rotterdam and Glasgow
}

\author{
Brian Doucet, Ronald van Kempen, Jan van Weesep \\ Faculty of Geosciences, Urban and Regional Research Centre Utrecht, Utrecht University, \\ PO Box 80115, 3508 TC Utrecht, The Netherlands; e-mail: doucet@geo.uu.nl, \\ r.vankempen@geo.uu.nl, J.vanweesep@uu.nl \\ Received 12 October 2010; in revised form 7 January 2011
}

\begin{abstract}
Gentrification - the creation of affluent space-has evolved from a sporadic and spontaneous process focusing on individual households into a municipal goal in and of itself, either in existing neighbourhoods, or in new-build developments. This is increasingly being done through flagship newbuild gentrification projects. This paper examines why and how this strategy has been implemented in Rotterdam and Glasgow through a study of two projects: the Kop van Zuid and Glasgow Harbour. By using a comparative approach, it sheds further light on reasons for pursuing this municipal goal, and examines how large new-build flagship gentrification is used to help realise these aims. It reveals a discourse in which the rationale of this policy is linked to the attraction and retention of affluent households, a lack of which, it is believed by policy makers, hurts urban competitiveness. It shows that this discourse is present and influences these two projects despite the different compositions of actors involved (the municipally led Kop van Zuid and the developer-led Glasgow Harbour). However, the ways in which this goal is implemented vary according to the local contexts and the different roles ascribed to the various stakeholders.
\end{abstract}

\section{Introduction}

"The problem with Rotterdam is that it's a rich city with poor people."

This quotation, taken from a civil servant working with the city's department of housing and urban development, illustrates a major challenge facing Rotterdam and other older industrial cities. These once wealthy cities have lost much of their affluent population and have become home to high concentrations of poverty and social deprivation. It also alludes to the idea that gentrification policies encouraging 'rich' people to settle in the city can be an appealing solution to this problem.

Gentrification is now seen to have moved beyond its original definition of the effects of individual household decisions, as first coined by Glass (1964), to being part of a much larger class remake of the inner city, and part of a wider strategy for urban redevelopment and regeneration (Harvey, 1989; Smith, 2002; Warde, 1991). As such, the process includes not only the upgrading of existing housing, but also developments such as new-build housing (Davidson and Lees, 2005), and flagship or megaprojects (Bianchini et al, 1992; Diaz Orueta and Fainstein, 2008; Fainstein, 2008; Lehrer and Laidley, 2008; Moulaert et al, 2003). These types of projects have increasingly been seen as part of the gentrification process because of their upward class transformation of urban space (see Davidson, 2007; Davidson and Lees, 2005; Murphy, 2008; Smith, 2002; Vicario and Martínez-Monje, 2003; Visser and Kotze, 2008).

Gentrification as an urban policy objective can be seen in cities throughout the world (Glynn, 2008; Hackworth and Smith, 2001; Lees, 2003; Lees and Ley, 2008; Loopmans, 2008; Moulaert et al, 2003; Slater, 2004; Smith, 2002; Uitermark et al, 2007). However, there is still a lack of evidence concerning the policy discourses behind the pursuit of such a strategy. This is particularly true when it comes to international 
comparisons of the municipal goals associated with gentrification, especially with regard to new-build projects in cities further down the urban hierarchy.

The main aims of this paper are twofold: first, to analyse the reasons for pursuing the municipal goal of gentrification and to examine the role which new-build projects play within it. A second goal is to understand how this is formulated and implemented under different political-economic contexts. This is important because we still lack a detailed study of the discourse behind the pursuit of this strategy from municipal leaders and other urban boosters. The way in which this global strategy is implemented in different contexts is an underresearched part of the debate. Therefore, a comparative approach has been selected, using two cities with similar industrial trajectories, albeit in which the local context creates a different hierarchy of actors: the municipally led Kop van Zuid in Rotterdam, and the developer-led Glasgow Harbour in Scotland.

This research builds upon a small but strong body of literature on direct international comparisons of gentrification and flagships (see Fainstein, 2008; Harris, 2008; Swyngedouw et al, 2002; Tasan-Kok, 2010; van Criekingen and Decroly, 2003). Swyngedouw et al (2002) examined the ways in which macroforces, such as globalisation and neoliberalism, influence the governance of large flagship projects; our work focuses on the perspectives and positions of policy makers themselves as to why their cities have actively promoted gentrification through new-build developments. A comparative approach, as Harris (2008) notes, is important for understanding the global spread of the process, while being sensitive to the different geographic and historic contexts. This idea is central in our evaluation of whether or not similar municipal goals are evident under different political-economic models.

The remainder of the paper is structured as follows. Section 2 focuses on the debates surrounding new-build gentrification and gentrification as an urban policy strategy. Section 3 introduces the two cities and their respective development projects, our research methods, and the stakeholders concerned with the two projects. In section 4 we concentrate on Rotterdam Council's vision of creating affluent housing on a former harbour site, and in section 5 examine how municipal goals in Glasgow became implemented in a project where the private sector was in charge. Finally, in section 6 , we offer some conclusions and place each case study within the wider context of gentrification and urban entrepreneurialism.

\section{On the changing forms of gentrification}

One of the ways in which gentrification has evolved from a small and spontaneous process involving individual households towards a much larger urban strategy is through the use of new-build and flagship developments. Davidson and Lees's (2005) work on London's new-build riverside developments has sparked interest and debate concerning the way in which gentrification is perceived and defined. Their work, however, builds on a long tradition of conceiving gentrification and large flagship urban development projects as part of the same process of upward class transformation and change (Bianchini et al, 1992; Harvey, 1989; Smith, 1996). In this section we review the arguments for and against considering these developments as part of the gentrification process.

\subsection{Arguments for and against new-build gentrification}

There are some scholars who argue that, under its current guise, a gentrification definition which takes into account transformations such as new-build projects is either too broad or too cumbersome to retain any analytical use or meaning. The main opponent of considering new-build projects as gentrification is Boddy. $\mathrm{He}$ argues that "gentrification is almost too quaint and small scale a concept to capture the 
process at work" (2007, page 103). Some authors prefer to use the term 'reurbanisation' instead (see Buzar et al, 2007). There are several main arguments against viewing newbuild projects as gentrification. First, there is no room for the aesthetic of authentic historic buildings and features which are qualities appealing to many gentrifiers (see also Jager, 1986). Second, different urban visions exist between those upgrading and living in historic properties and those inhabiting new-build projects (see Lambert and Boddy, 2002). A third argument is that describing new-build projects in this way is largely political in nature (Boddy, 2007). Many of the proponents of considering these developments as part of gentrification come from a critical perspective, and built their work focusing on the class struggles and social injustices of the process. Boddy argues that by describing new-build developments in this way they can tap into the opposition and critical history of gentrification research, attempting to keep a critical perspective on current aspects of urban development. The fourth, and perhaps most compelling, argument is that no direct displacement exists: Boddy (2007) argues that it is erroneous to refer simply to price exclusion (expensive housing costs in new-build developments) as a form of indirect displacement.

There are many arguments for considering new-build projects as part of gentrification and this case is made most emphatically by Davidson and Lees (2005), who see such projects as 'one of the mutations' of gentrification (page 1166). Again, there are several arguments. First, the supply-side theorists believe that gentrification is caused by movements of capital flows and the closure of the 'rent gap' (Smith, 1979; 1996; see also Lees et al, 2008); new-build projects fit within these parameters because they bring investment into blighted and underutilised parts of the city. A second argument is that there is indeed displacement, though through indirect or sociocultural means (Davidson, 2008; Davidson and Lees, 2005; Marcuse, 1986; Spain, 1993). For example, prices of the new-build properties, changes in tenure, and different cultures and values led to fears amongst residents in the East End of London that the Docklands development was aimed at replacing them with a new community (Brownill, 1990, pages $80-83$ ). Third, notwithstanding modifications to the built environment, the landscapes of gentrification which are produced and sold by architects, developers, and estate agents are also similar to earlier forms (Davidson and Lees, 2005; Mills, 1988). And fourth, the inhabitants who settle in new-build projects also come from similar middle-income and upper-income backgrounds (Davidson, 2007) - the so-called 'urban seeking' group (Butler, 1997). Under this definition, class transformation is inherent to the gentrification process (see also Slater, 2004; Smith, 1996); this perspective is echoed in the theoretical framework of Harvey (1989) and can be seen in empirical cases described by others (eg Murphy, 2008; Visser and Kotze, 2008).

\subsection{Gentrification as an urban strategy}

Since van Weesep (1994) first called for the gentrification debate to be put into the policy perspective, there have been numerous studies which have focused on the policy aspects of gentrification, or on gentrification as an urban strategy (Badcock, 2001; Hackworth and Smith, 2001; Lees and Ley, 2008; Loopmans, 2008; Slater, 2004; Smith, 2002; Uitermark et al, 2007). However, despite these studies, our understanding of why and how this policy is implemented (from the perspectives of policy makers themselves) in different local contexts remains limited.

Gentrification has been supported by state mechanisms in one way or another almost since its inception, through instruments such as improvement grants and heritage designations (Hackworth and Smith, 2001; Lees and Ley, 2008; Walks and August, 2008). However, in recent years it has become part of larger neoliberal goals (Glynn, 2008; Harris, 2008; Moulaert et al, 2003; Murphy, 2008; Smith, 2002). 
This can be seen particularly in the USA and UK, where the division between 'gentrification' and 'urban regeneration' is often blurred, and gentrification is seen in urban policy as "a blueprint for a civilised city live" (Lees, 2000, page 404). The support for building of new middle-class housing on brownfield sites clearly fits this blueprint.

As a result of this more concerted government emphasis towards fostering gentrification, it has undergone something of an image makeover in recent years (Davidson, 2008) - so much so that many cities actively and officially seek to cultivate and promote these types of neighbourhoods. In a framework in which cities promote themselves as exciting and dynamic places to live, invest, and play, gentrified spaces are actively promoted and even celebrated amongst policy makers and urban boosters. Ideas such as Florida's (2002) 'creative class' have become a holy grail by which to improve cities: creating exciting and dynamic neighbourhoods as a way to attract affluent residents. Lees and Ley (2008) note that over the past thirty years gentrification has changed from a problem for urban policy to a solution and has become central to urban policy. It has come to be seen by many policy makers as a way of creating more socially inclusive, liveable, and sustainable communities (Lees, 2008), and has also become a major element in social mixing policies (Davidson, 2008; Gutzon Larsen and Lund Hansen, 2008; Lees, 2008; Uitermark, 2003; Uitermark et al, 2007). Outside of a segment of the academic community and local activists, the negatives associated with gentrification (displacement, conflict, equity) have either been ignored or marginalised, so that a positive discourse has emerged which celebrates the process as part of an urban renaissance (see Slater, 2006).

Within urban policy, the embracing of gentrification is furthering the transition away from using housing developments as a means of wealth distribution, as was evident in the construction of large postwar estates in Western Europe (Eisinger, 2000; MacLeod, 2002), and towards urban entrepreneurial strategies in which cities focus on housing as a means of wealth creation and urban boosterism. In countries such as the UK, there has been an ideological switch towards favouring the private sector, rather than planning agencies, for regeneration (Brownill, 1990). The change from social objectives towards growth-oriented goals has furthered socioeconomic polarisation in many cities (Swyngedouw et al, 2002). Local governments, rather than ensuring an adequate supply of affordable and good-quality housing, have been drawn into the role of developer (either directly or indirectly), risk taker, and investor under the guise of economic development and urban competitiveness.

Urban entrepreneurial strategies, especially those aimed at attracting affluent residents, in particular can be seen in older industrial cities further down the urban hierarchy. While classical gentrification studies have branched out towards more provincial cities (see Bridge, 2003; Dutton, 2003), the role of new-build gentrification in urban policy in such cities has yet to be thoroughly examined. McIntyre (2008) states that the biggest challenge regarding gentrification for older industrial cities, such as Glasgow, is to bring employment and population back to the city. This is a very different goal from that in London or New York, where middle-class households are naturally drawn to these global cities. How this challenge is answered in urban policy is examined in more detail below.

One of the aims of this paper is to show how new-build gentrification projects have become implemented under different political-economic contexts, particularly when this context ascribes different positions to the varying actors. It is important to stress that, although the phenomenon is global in its reach, it is implemented with local nuances. Despite being a global urban strategy (Smith, 2002), there is still little evidence to illustrate how different contexts influence the outcome. Harris (2008) 
argues that "such an analysis is required to investigate how the global spread of gentrification like the extension of market rule through neoliberalism operates through different urban economic bases, social hierarchies, cultural histories and institutional frameworks" (page 2410). We might, therefore, expect to find significant differences in the ways in which this strategy is implemented, and the eventual outcomes, because of these differences.

For studies focusing on the role in which the local political context plays we must turn to research on megaprojects, where more attention has been paid to comparative governance and contextual issues. Fainstein's (2008) work comparing megaprojects in New York, London, and Amsterdam stresses the physical similarities of these developments, while highlighting that the political-economic context is important in understanding the social goals which are formulated. Here she demonstrated the differences between the American and European models, and showed that the size of the direct government commitment influenced the subsequent amount of public benefits. Tasan-Kok's (2010) study of the governance of two waterfront projects (the Kop van Zuid and a project in Antwerp, Belgium) highlighted how they are influenced by the macrolevel institutional context. She attributes the success of the Kop van Zuid to its top-down organisational structure, compared with the more ambiguous task allocation in Antwerp. In a major study of urban development projects in the EU, Swyngedouw et al (2002) focused more on the similarities in urban restructuring under new forms of entrepreneurial governance than on the differences between cities. Like Gutzon Larsen and Lund Hansen (2008), they argue that such projects focus on the competitive positions of their economies within rapidly changing conditions.

While these works shed light on the way in which such projects are governed, and the role of large macroeconomic and social forces involved, we still do not know enough about how the composition of actors influences the goal formation behind new-build developments, or the specific policy rationales of those in charge of actually pursuing this strategy. In the remainder of this paper we turn to two new-build flagship gentrification projects in order to understand how and why they were used to foster gentrification aims, and to understand the differences which local context plays.

\section{Research methods and case studies}

Research for this paper was conducted through interviews with the most important stakeholders involved in both the Kop van Zuid in Rotterdam and Glasgow Harbour. In total thirty-one semistructured interviews were conducted, averaging seventy minutes in length and conducted in the mother tongues of the interviewees. In addition, policy documents centred on urban housing strategies were consulted and analysed.

An international comparison was selected to show the global spread of these patterns while paying attention to the nuances and local and historical contexts which may affect the outcomes (see Harris, 2008). The two cities of Rotterdam and Glasgow were selected because both are industrial, maritime cities which have been active in using entrepreneurial approaches to urban governance. After long periods of decline and stagnation, they both experienced revivals in the early part of the decade. The two largest waterfront developments have been chosen as case studies: the Kop van Zuid and Glasgow Harbour.

Both cities have experienced similar economic histories. Their rises to prominence and prosperity in the 19th and early 20th centuries were based on shipping and maritime activities: Glasgow became the leading shipbuilding centre of the world, which helped give it the status of the 'Second City of the Empire', and Rotterdam 
rose to become one of the world's biggest ports. The waterfronts were industrial and working spaces. This growth and prosperity attracted large numbers of migrants to the cities (from the Highlands and Ireland to Glasgow, and from Zeeland to Rotterdam), creating large and often overcrowded working-class neighbourhoods in the inner city. However, with deindustrialisation and changes in the logistics industry in the latter half of the 20th century, both cities experienced sharp declines. In Rotterdam, many innercity neighbourhoods became home to high percentages of people from different ethnic backgrounds, particularly from Turkey, Morocco, or former Dutch colonies [for an excellent account of one such area in Rotterdam South, see Blokland (2001)]. In Glasgow many working-class areas experienced deprivation and depopulation (see Keating, 1988).

The overrelieance on labour-intensive manufacturing and shipping meant the loss of thousands of jobs and the devastation of neighbourhoods. Population loss has been both absolute and relative: large numbers of affluent and highly skilled residents have moved out of both cities. Because of these challenges, they have been among the first cities to adopt growth-oriented entrepreneurial approaches to governance, as witnessed through their hosting of major events (such as the European Capital of Culture), their efforts at branding and marketing, and, more recently, their support of flagship regeneration projects.

However, the local contexts of governing and planning urban regeneration are very different. The Dutch model of urban planning gives significant power to local governments. This enables strong master plans to be developed. In Scotland (and the UK in general), private developers play a more central role in such projects, and state intervention has been limited (Brownill, 1990). The role of the municipality, rather than guiding and leading projects, is to approve, through established bureaucratic mechanisms, developer-led plans. Those master plans that do exist are far weaker and less holistic than in the Dutch context.

Rotterdam is the second-largest city in the Netherlands, and still one of the largest ports in the world. The city's major flagship project is the Kop van Zuid, a mixed-use development of housing, offices, leisure, and infrastructure, situated on the south side of the River Nieuwe Maas, directly opposite the city centre. Planning for the project began in the late 1980s, and the development progressed rapidly after the completion of the iconic Erasmus Bridge in 1996, which linked the development (and Rotterdam South) with the city centre on the north side of the river.

Rather unusually among flagship projects, social goals have played a role in the development of the Kop van Zuid [see Swyngedouw et al (2002) for research on social returns in major European projects]. A central vision for the Kop van Zuid was for it to become an economic, social, and physical unifier for the city, which has historically been divided by the river. However, the economically oriented goals are representative of other similar waterfront projects (Eisinger, 2000; Harvey, 1989), and focus on improving the city's economic position. The initial goal of creating high-quality and high-profile international office space gave way to economic goals focused on the construction of affluent housing - both flats and single-family dwellings (see Doucet, 2009; Kop van Zuid, 1995; 1999).

Because it is a municipal project, most of the stakeholders interviewed for this research came from the city of Rotterdam. The majority came from either the Rotterdam Development Corporation (OBR), an agency in charge of stimulating economic investment in parts of the city not likely to see development on their own, or the department of housing and urban development (DS+V), as these branches of the local government were the most active in the planning of the project. This included the spearhead of the project, Ms Riek Bakker, the current project leader, and the chief 
planner. However, as the task of actually building and selling the houses was given to the private sector, representatives from developers, builders, and urban designers were also interviewed. Additional interviews included some with representatives from three local housing associations. The interviews were conducted between January 2008 and February 2009.

In Glasgow the deindustrialisation of the Clyde riverfront led to large tracts of vacant land along the waterfront, as well as the deterioration of adjacent neighbourhoods which housed the former factory workers. However, comprehensive postindustrial redevelopment has not taken place along the river: there are many one-off projects, such as the Scottish Exhibition and Convention Centre (SECC), a new headquarters for BBC Scotland, a new science museum, and several smaller housing developments which have had varying degrees of success. However, waterfront redevelopment is still characterised as patchy, and large plots of vacant and underused land still exist, even close to the city centre (see Tiesdell, 2009).

Glasgow Harbour represents the largest waterfront investment in the city to date. It is situated on the north bank of the Clyde, around $3 \mathrm{~km}$ west of the city centre, in the prestigious West End and close to Glasgow University. To the north is the neighbourhood of Partick, which is a mix of working-class and gentrified homes.

Being a brownfield site, it fits with the UK government's vision for urban regeneration in and near city centres (see Davidson, 2008; DETR, 2000; Lees, 2008). Currently, the project consists only of residential units of one or two bedrooms, located in apartment blocks; later phases will include the Riverside Museum, home to the Museum of Transport, which is scheduled to open in 2011, as well as retail and leisure facilities which are still in the planning stages.

Glasgow Harbour Ltd is a subsidiary of Clydeport, the former managers of the port of Glasgow, who have become more and more involved in the propertydevelopment game. They were the principal landowners of the site and have been the driving force behind its regeneration. While fitting within the city's framework for populating the waterfront, the specifics of the project have been left to Glasgow Harbour Ltd. Decisions such as focusing on housing first (instead of a mixed-use project), flats only, a lack of social facilities, and the specific locations of the phases of development within the site have been decisions made by the developer, not the city. Provisions for social housing do not exist.

Because of the different composition of stakeholders governing Glasgow Harbour, the interviewees were different from those in the Kop van Zuid. The head of Clydeport as well as the planning consultant were both interviewed, as were private house builders contracted to construct and sell the properties. From the city council, interviews were conducted with a planner for the waterfront, a housing officer from the Development and Regeneration Services, and the four local councillors for the area. A representative from one of the local housing associations was also interviewed. Interviews were conducted between September 2008 and January 2009.

\section{Municipality-led waterfront regeneration in Rotterdam}

\subsection{Attracting high-income residents: an explicit municipal goal}

In Rotterdam, gentrification of inner-city neighbourhoods has become an explicit policy aim. As we show in this section, the main reason behind this is a belief amongst policy makers that the city has a shortage of middle-class households. As a result, attracting and retaining these groups features prominently in the city's housing discourse.

Rotterdam, like all Dutch cities, historically had high levels of social-rented housing. By the 1980s this came to be seen as a liability which prevented growth and investment. Being an older industrial city, the problems were more acute in Rotterdam 
than in other big cities in the country. As one observer, working within the city's DS+V noted:

"they said that all this attention to social housing had to change. Then they said that

Rotterdam was a city lacking in a vast number of middle-class people as you have in The Hague or Amsterdam."

This was seen as adversely affecting the city's national and international competitiveness. In 2000 the city decided to stop the promotion of social housing construction in order to encourage differentiated neighbourhoods (Uitermark and Duyvendak, 2008).

The focus away from social-rented housing towards housing for more affluent groups can be seen in the city's official Urban Vision, released in 2007 (Gemeente Rotterdam, 2007). It focuses to a great extent on housing quality and differentiation, creating the type of neighbourhoods aimed at attracting the types of residents mentioned above. It makes direct reference to footloose residents:

"One of the main aims of our development strategy is a balanced composition of the population. This can be most effectively achieved by counteracting selective migration. The city should be so attractive, that Rotterdammers would not tend to leave... . The city must appeal to residents who can choose freely from a range of alternatives in the housing market" (Gemeente Rotterdam, 2007, page 63, authors' translation, underline in original).

While many official policy documents in other cities shy away from using the term 'gentrification', Rotterdam is explicit in its promotion of the process. The Urban Vision outlines this strategy:

"these districts [neighbourhoods adjacent to the city centre] are increasingly popular among (former) students and those active in creative industries; these are exactly the groups Rotterdam wants to attract. In social, cultural and economic terms, these districts have the features necessary for an autonomous gentrification process... . The municipal authorities support this process with appropriate measures" (Gemeente Rotterdam, 2007, page 70, authors' translation).

Rather than being seen as a 'dirty word' (Smith, 1996), for the municipality of Rotterdam, gentrification is heralded as a saviour which will help revive and stimulate the city.

Why has a policy developed which encourages both new-build and more traditional forms of gentrification? Two reasons can be seen from the interviews conducted with key stakeholders of the Kop van Zuid project. First, Rotterdam was a city with a high percentage of lower income households and relatively few affluent ones. This stems from the city's economic history, based on industrial and maritime activities. Policy was therefore geared towards the attraction of knowledge workers which would thereby stimulate the creation of a postindustrial Rotterdam.

The second reason had to do with a lack of housing supply. The city had a distinct lack of owner-occupied housing stock; with such a high percentage of the city's housing stock comprised of social-rented units, there were fewer opportunities for homeownership and, therefore, equity accumulation. Those who achieved success left the city for the more spacious and comfortable single-family houses in one of the many satellite towns around Rotterdam. This lack of supply also made the city less attractive to potential residents in terms of their choice of where to live in the region. As a stakeholder from the OBR noted:

"You want to keep the people here who were brought up [in Rotterdam], studied here, and have a job here. What happens now is that these people move to the suburbs .... They all leave now. And we do not want that. We want to keep them here." 
These two factors served to reduce the attractiveness of Rotterdam to middle-income groups. Even the city's student population largely left after their studies, for many of the aforementioned reasons. The link between students and gentrification has been noted in the academic literature (see Smith, 2008; Smith and Holt, 2007), and keeping graduates in Rotterdam is part of the strategy employed by the council.

In Rotterdam, then, gentrification is a municipal goal, and is openly promoted as such as a way of counterbalancing the perceived problems of being an old industrial city dominated by lower income groups. The aim is to attract and keep footloose affluent residents in order to have the type of population seen as necessary for economic success. In the next section we outline how the flagship Kop van Zuid project has been used to further these objectives.

\subsection{Attracting high-income residents: the role of the Kop van Zuid}

In the 1980s the original housing plans for the Kop van Zuid entailed the area becoming a spillover neighbourhood for residents temporarily displaced during restructuring of their own neighbourhoods. It would have been another neighbourhood of social housing. However, the plans quickly changed to make it a higher end, newbuild neighbourhood. As we have seen, this fit within the general housing policies of the city of Rotterdam at that time.

Much of this change in vision can be attributed to Ms Riek Bakker. As coordinator of the project and head of urban development for the city of Rotterdam, she was influential in rejecting the idea of using the land exclusively for social housing. As she stated during an interview:

"[Rotterdam] South was $90 \%$ social housing ... . We said you have to build something else. You must build more expensive housing there, not only social housing, but also for wealthier inhabitants."

Her vision thus centred on maximising the economic potential for the land, while at the same time focusing on social improvements, and this vision was to guide the project over its various stages.

As it was a municipally led project, the city could realise the vision set out by Ms Bakker. This was influential in setting goals for the project, one of which was upgrading the housing environment of the city (Kop van Zuid, 1995). Differentiation of the housing stock, away from low-income housing towards more diversity in the supply of housing, was the main intention. There was a focus on providing good-sized apartments, houses with gardens, and good-quality dwellings. These were features which Rotterdam's housing stock lacked at that time, whereas competing suburban municipalities around Rotterdam offered a large supply of this sort of housing.

The city was in charge of setting the goals for the Kop van Zuid largely through its master plans. However, the task of building the individual developments was left to private actors. But because this was a municipally led project, the developers were fulfilling a mandate from the city to build high-end housing, rather than proposing it themselves (although they were eager to take up the offer). This partnership proved beneficial for both parties.

That the city was firmly in charge of its vision is evident in the relatively straightforward explanation of how the goal of gentrification was achieved (figure 1). The Kop van Zuid used a top-down approach. It is a state-led, new-build gentrification project, where other parties follow the intentions and ambitions of the city. It is a product of its political-economic system which, in the Netherlands, gives the task of controlling urban regeneration projects to the public sector. 


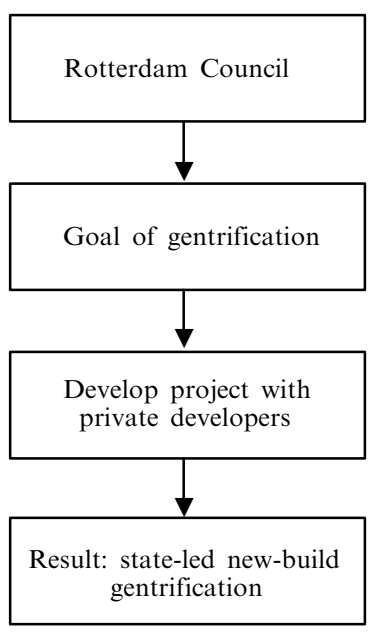

Figure 1. Development of gentrification in the Kop van Zuid.

The combination of the policy goal of attracting and retaining middle-class residents, combined with the organisational structure of the Kop van Zuid, meant that the city could use the development to further these objectives rather easily. The Kop van Zuid created new housing in Rotterdam of types which were generally lacking: large luxury flats and single-family houses. Its success has led to similar types of municipally led gentrification in other neighbourhoods. Although it has furthered certain policy aims, it has also created divisions within the city. However, the creation of affluent space is not necessarily seen as a negative, as one of the project's leaders illustrated:

"you have to have a good job if you want to live here.... People without a job, or with a bad job, or a relatively low salary, they cannot live on the Wilhelmina Pier, no. But they also can't live in Hollywood."

The housing aim of the Kop van Zuid is to create an affluent neighbourhood which would be popular with the types of households Rotterdam is trying to attract and retain. This is an explicit aim. As such, this new-build flagship is part of the gentrification process. It is, in essence, a response to the challenge of Rotterdam being a 'rich city with poor people.'

\section{Developer-led new-build housing in Glasgow Harbour}

\subsection{The need for residents: Glasgow's (high-end) housing needs}

Glasgow shares many of the same problems with Rotterdam. One of these is a lack of high-income residents, compared with other cities in the region. This stems in part from trends of the postwar years, when upwardly mobile residents were encouraged to leave the densely populated city and settle in the new towns being built at that time on the periphery. Decentralisation became the main aim, partly because of the terrible overcrowding in the city's older neighbourhoods (Keating, 1988). This era was characterised by urban managerialism; the aim was provision of better quality housing for the urban population. More than half of the city's inhabitants lived in social housing, and the large housing programmes of the postwar era included slum clearances in the centre, and the creation of four peripheral housing estates to house those displaced by these clearances.

Currently the official strategies guiding Glasgow, outlined in the City Plan, and updated in the City Plan 2 (Glasgow City Council, 2008), focus on a two-pronged 
housing approach. In the first instance, the city council wished to stem the tide of out-migration from the city by supporting the development of middle-class housing aimed at professionals. This is also part of a wider strategy to attract creative industries, foster tourism, and encourage inward investment. Fitting with urban entrepreneurial strategies, the aim is to make the city an exciting and dynamic place to live, work, and invest. The spatial focus of this strategy has concentrated on the city centre and much of the Clyde waterfront. The goal is maximising the economic and social potential of the riverside (Glasgow City Council, 2005). This approach is balanced by the second strategy: ensuring that there is sufficient good-quality affordable housing. Here the focus is on more peripheral locations, such as the East End, and the major postwar housing estates.

Again, as with Rotterdam, the population loss experienced was both a net and a relative, or socioeconomic, one. In Glasgow, however, these declines were more extreme, as were the economic and social problems of the city. This has resulted in a housing policy aimed more at absolute population growth, rather than specifically targeting only higher income groups. As one council official stated:

"Glasgow's attitude really has been that we need to get any population we can ... the city's halved in population over the last fifty years .... There's been much less of a debate in Glasgow, really, about the kind of housing, kind of market, than there would be probably in most places. Because, the attitude has been if anybody wants to come and live by the riverside, we'll facilitate it."

Not only confined to attracting higher income groups to the city, this policy also included settling asylum seekers under the Home Office dispersal programme. As the same interviewee noted, "Glasgow's concern was less specifically about getting betteroff people." In Rotterdam, in contrast, previous councils had crafted policies which tried to limit the numbers of lower income residents arriving in the city (see Uitermark and Duyvendak, 2008).

However, like Rotterdam, there was also the belief that too many higher income households had left the city, as one local councillor noted:

"Department of Regeneration Services has always made it quite clear that the idea is trying to keep population, and high earners, within the city boundaries... I don't

know if many people would actually admit that, within the Council offices, but certainly from talking to people in the community, that's certainly what a lot of people have a view of."

Several respondents noted that this was more of an implicit goal, rather than something which was either openly discussed or featured in official policy documents. But the belief that the city needed both people and professional people was a viewpoint upon which all stakeholders agreed. A local planner, when asked about the goal for the waterfront of bringing inhabitants to the city, responded that it was:

"to bring people to the city. Because once they're paying their taxes, that's money in for the city. Because previously, you know, it's been people leaving the city, for twenty or thirty years... and of course, those people [returning], the more wealthy they are, the more spending power they have, and the more they'll spend in the city as well, which is a good thing. That means more people employed in the retail and restaurant industries, etc etc. So, that's the raison d'être of the whole strategy."

The goal of redressing the socioeconomic imbalances within Glasgow is somewhat blurred by the city's desire to attract any residents, in addition to higher income ones. However, examining this discourse spatially, it becomes obvious that the municipality has the view of turning the waterfront into a high-quality urban environment aimed at professionals and more affluent groups. 


\subsection{The need for residents: the role of Glasgow Harbour}

Glasgow Harbour plays a large role in implementing the strategy of attracting and retaining high-income residents. However, because the municipality does not have direct control over the developer-led project, they must use planning support in order to achieve this. The private sector goal of creating a profitable and prestigious development along the riverfront overlaps with the city's goal of attracting affluent residents. Although each of these goals is separate, they led to the same outcome: the creation of a new-build gentrified development along the Clyde. This enabled the city to support the project, even though it has limited control over it The city's role, rather than leading the project, was to support and facilitate it - through planning. The city has welcomed and aided this type of development, partly because Glasgow had been starved of investment until recently and partly because it was fitting in with its vision of urban development. Glasgow Council is behind the project as it fits within its vision for a repopulated waterfront and its goal of middle-class growth. This was noted by a planner whose remit includes the waterfront:

"We get people to live in here, we'll collect more rates, so that means we have more money to do the things we want to do in the city (roads, lighting, parks, safety) ... . But as you can see, we don't have a huge control over that investment. All we can do is welcome it, and where we can, make it easy for them to invest."

Despite criticism from researchers and the media, there was little official opposition to the project from within the city council. On the contrary, this type of development was welcomed and seen as one of the only real alternatives for urban development along the river. This mirrors results of other studies which have found that neoliberal goals are embraced in gentrification and new-build projects (Davidson, 2007; Glynn, 2008; Murphy, 2008; Smith, 2002).

That the city was behind the project, and the idea of attracting affluent residents to brownfield sites more generally, is reflected in the words of a local councillor from the area:

"It's interesting because one of the... criticism[s], sometimes it is quite an explicit criticism, oh you want to build all these yuppie flats just to attract rich people to live in the city. And I would actually have to say, 'well, could you kind of explain to me what exactly is wrong with that?' I mean what's wrong is if at the end it denies other people access to housing, but that actually hasn't been, it isn't the case with the Harbour development. Because it wasn't the case of a community being displaced so that these flats could be built, it was urban industrial land. So whilst I think it's a valid criticism to say that there should be more socially mixed housing, I don't feel that there was anybody displaced to make way, and as you see, yuppie, young urban professionals, they just don't want those type of people to live in the city."

This quotation gives insight into why fostering gentrification through new-build projects is so attractive to politicians and policy makers: it brings only perceived benefits, while the negatives associated with more traditional gentrification can be easily dismissed.

While the city council favours this type of development, which it believes will help it to meet its goals, it must use planning support for private developers, rather than direct intervention, in order to achieve them. With the case of Glasgow Harbour, this has been done by not placing too many restrictions on Clydeport and other developers, particularly when it came to planning gain, infrastructure, or public realm improvements. Because the goals of the different stakeholders lead to similar outcomes, the developers have been able to build with little restriction from the council. As a result, the city's goal becomes realised, albeit in a roundabout way (see figure 2). 


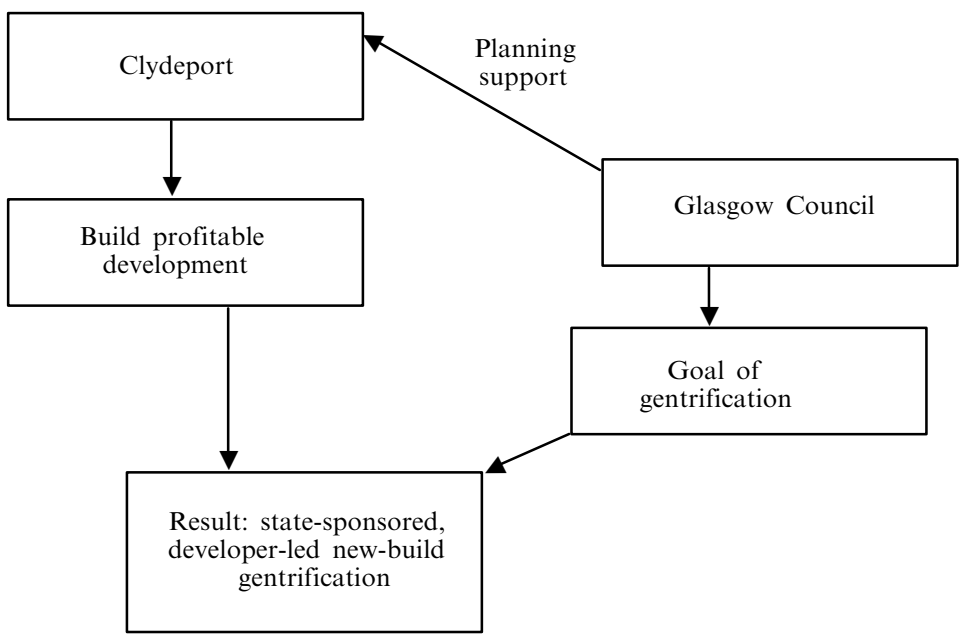

Figure 2. Development of gentrification in Glasgow Harbour.

In Glasgow Harbour the role of the city is to facilitate the building of affluent-occupant housing by private developers. Both parties have the same goal: a prosperous waterfront populated by middle-class households. Planning is the main way in which this relationship works. The city has not placed too many restrictions on Glasgow Harbour, and demanded little planning gain from the project (apart from the infrastructure improvements to the site itself). Since the 1990s the city has adopted a developer-friendly approach to urban regeneration (Tiesdell, 2009). A lack of planning restrictions and a sense that the city was happy for any development are characteristics both of Glasgow Harbour, and of the wider Clyde regeneration in general. However, the city still supports projects which further its goals, although the council is more limited in the direct influence it has. Like Rotterdam, official municipal opposition is minimal (though Glasgow Harbour is not without its critics).

\section{Conclusions and discussion}

Municipal support for the creation of new-build gentrified housing, through a variety of mechanisms, is an accepted form of urban redevelopment. What we have seen in Rotterdam and Glasgow is that the support for new-build gentrification projects is a direct result of the belief amongst policy makers that their cities suffer from a lack of affluent residents and that the easiest way to redress this imbalance is to create the types of gentrified spaces which appeal to these groups. Gentrification in this context is not about the upgrading of historic housing, or the improvement of existing neighbourhoods. Rather, it is a policy choice centred on attracting and retaining footloose affluent households. Gutzon Larson and Lund Hanson (2008) argued that this strategy is pursued in order to remain competitive. In Rotterdam and Glasgow, urban competition is centred on human capital: using the (new-)built environment to create neighbourhoods which will be attractive for professionals and 'creative' workers. In this paper we have attempted to further our understanding of gentrification and urban policy by delving deep into the rationales and discourses behind two cases in different political-economic contexts.

In Rotterdam this was a very explicit strategy, evident both in policy documents and through interviews with key actors involved in the Kop van Zuid from both the public and private sectors. This shows evidence of pro-growth urban entrepreneurialism: despite the social orientation of some aspects of the project, the specific growth-oriented goal 
of attracting affluent households through the creation of appropriate housing has been realised. Because the city was in charge, it was a relatively straightforward matter, developed through strong visions and goals. In Glasgow this strategy also was evident, though much more implicit. The city was happy to support Clydeport in its plans to build a high-end housing development along the waterfront because both parties shared a similar vision for the regeneration of the Clyde as affluent and prestigious space. The advantage for Glasgow Council was that it could get this development virtually for free. The main disadvantages were that the Council had limited influence on the specific plans for Glasgow Harbour, particularly with respect to linking it to the rest of the city, and obtaining social benefits from that investment. This has resulted in a development which has been heavily criticised as yet another one-off isolated enclave-type project, instead of one which is fully integrated into its surroundings and the wider city.

New-build projects are being used to further municipal gentrification ambitions in both cities and the reasons behind this strategy are similar. This is despite the different political-economic contexts, which severely limit the city's power in Glasgow: the master plans created in Glasgow are much vaguer than in Rotterdam, and still ultimately give developers the power to build what they think will be most profitable. The formulation of goals in Glasgow was also much weaker than in Rotterdam. It can be argued that the goal of gentrification was achieved more successfully in Rotterdam than in Glasgow: there are more types of housing stock (family homes, apartments, and the like) and the neighbourhood has been seen as more of a success than Glasgow Harbour. At first this may appear counterintuitive: municipally led affluent housing worked better than that led by private developers. However, the combination of entrepreneurial urban policies adopted by the city of Rotterdam, along with strong spatial planning and goal-setting seen in Dutch urban governance, has led to a project which has achieved what it set out to become. In her work comparing waterfront developments in Antwerp and Rotterdam, Tasan-Kok (2010) also noted how this model was successful in bringing projects to fruition; here, we see that this model also leads to goals being more successfully achieved as well.

In both Glasgow Harbour and the Kop van Zuid, there has been a coalescence of sentiment among policy makers and developers backing middle-class redevelopment of the city. This is, of course, not exclusive to these two projects: Brownill (1990, page 67) highlighted the reasons for pursuing new affluent housing in London's Docklands as being focused on improving the image of the area, attracting commercial investors and attracting a different population. A positive discourse has been created in which progrowth urban entrepreneurial strategies go unchallenged amongst most politicians and policy makers; initiatives geared to middle-class consumption and housing have come to be seen as the strategy for urban regeneration (see Glynn, 2008; Loopmans, 2008). In this research we have attempted to delve deeper into why this strategy is seen as essential from the perspective of these policy makers.

This has been a very easy strategy to adopt (as was evident by the quotation from the Glasgow councillor in the previous section). There is no displacement, so why should you oppose it? New-build gentrification brings in the types of households that drive economic growth, so what is wrong with that? The negatives of class conflict, tensions, and displacement are not visible. That is why it can be so easy to support. This discourse of gentrification led by policy makers, not academics, promises to bring wealth to the city, be inclusive, and solve problems rather than create them. And because it is rarely named as such (in Rotterdam this is a notable exception), it has none of the negative 'baggage' associated with earlier debates on gentrification. This is why Rotterdam and Glasgow, cities with long traditions of municipal socialism, can now pursue gentrification - either explicitly, or implicitly, through new-build flagship projects. 
While this discourse may seem only beneficial in the eyes of policy makers and urban boosters, a far less obvious criticism exists, which is often overlooked when developing these urban strategies. This strategy rebuilds the city only for the sections of the population able to pay to live there. It does little to alleviate more pressing urban economic and social problems of unemployment, affordable housing, or sustainable jobs, apart from by indirect or trickle-down measures. In this sense, these projects further, rather than reduce, the preexisting social and spatial divisions within the city. They focus on wealth creation, rather than wealth distribution. This is why we must continue to question these strategies as a basis for a socially inclusive urban renaissance. This approach becomes problematic when it forms the hallmark of an urban housing strategy which claims to be creating a better city for all. Unfortunately, although strong amongst some sections of the academic community, the discourse focusing on the consequences of this approach is rarely evident in policy circles, particularly in cities which are searching for growth and development.

That is also why it is important to continue to consider these projects as gentrification. As Wyly and Hammel (2008, page 2645) state:

“using the term 'gentrification' is an analytical and political choice that matters, especially when asking questions of policy officials who have made the choice to avoid, redefine or suppress an uncomfortable word that so accurately describes the geographies being produced in many cities."

The term 'gentrification' carries a lot of negative associations; by showing that these developments are indeed part of the gentrification process, we can bring more balance to a policy discourse which has, in many circles, strayed towards absolute support.

Gentrification is a global urban strategy (Smith, 2002). This research has shown that the reasons for pursing this strategy in two older industrial cities stem from a drive to attract and retain footloose middle-class residents. Municipal leaders have concluded that their cities are failing to compete in attracting these groups because their housing supply is not conducive to middle-class lifestyles. These groups are seen to be the saviour of such cities. Therefore, municipalities must be proactive, in whatever ways their political-economic system allows, in increasing the supply of such housing stock. The hope and expectation is that the desired population will follow. The way in which this goal is pursued, however, varies between local contexts and does have an impact on the type of product which results. Fostering and supporting gentrification is seen as a necessity in urban policy circles and as one of the easiest and most visible ways of tackling the problem of being 'a rich city with poor people'. However, an important question remains: will this approach bring real economic benefits to the city and its inhabitants, or will it merely create small pockets of affluence in an otherwise poor city?

\section{References}

Badcock B, 2001, "Thirty years on: gentrification and class changeover in Adelaide's inner suburbs, 1966 - 1996" Urban Studies 38 1559- 1572

Bianchini F, Dawson J, Evans R, 1992, "Flagship projects in urban regeneration", in Rebuilding the City: Property-led Urban Regeneration Eds P Healey, S Davoudi, M O’Toole, D Usher, S Tavsanoglu (E \& FN Spon, London) pp 245-255

Blokland T V, 2001, "Bricks, mortar, memories: neighbourhood and networks in collective acts of remembering" International Journal of Urban and Regional Research 25268 -283

Boddy M, 2007, "Designer neighbourhoods: new-build residential development in nonmetropolitan UK cities - the case of Bristol" Environment and Planning A $3986-105$

Bridge G, 2003, “Time - space trajectories in provincial gentrification.” Urban Studies 402545 - 2556 Brownill S, 1990 Developing London's Docklands (Paul Chapman, London)

Butler T, 1997, Gentrification and the Middle Classes (Ashgate, Aldershot, Hants) 
Buzar S, Hall R, Ogden P, 2007, "Beyond gentrification: the demographic reurbanisation of Bologna" Environment and Planning A $3964-85$

Davidson M, 2007, "Gentrification as a global habitat: a process of class formation or corporate creation?" Transactions of the Institute of British Geographers, New Series 32490 - 506

Davidson M, 2008, "Spoiled mixture: where does state-led 'positive' gentrification end?" Urban Studies $\mathbf{4 5} 2385$ - 2405

Davidson M, Lees L, 2005, “New-build 'gentrification' and London's riverside renaissance" Environment and Planning A $371165-1190$

DETR, 2000, Our Towns and Cities - The Future: Delivering an Urban Renaissance Department of the Environment, Transport and the Regions (The Stationery Office, London)

Diaz Orueta F, Fainstein F, 2008, "The new mega-projects: genesis and impacts" International Journal of Urban and Regional Research $32759-767$

Doucet B, 2009, "A tale of two waterfronts: goals, roles and visions in Rotterdam's Kop van Zuid and Glasgow Harbour", paper presented at the RSA Old Industrial Regions Conference, The Regeneration of Image in Old Industrial Regions, Mönchengladbach, Regional Studies Association; copy available from the author

Dutton P, 2003, "Leeds calling: the influence of London on the gentrification of regional cities" Urban Studies $402557-2572$

Eisinger P, 2000, "The politics of bread and circuses: building the city for the visitor class" Urban Affairs Review 35316 - 333

Fainstein S, 2008, "Mega-projects in New York, London and Amsterdam” International Journal of Urban and Regional Research $32768-785$

Florida R, 2002 The Rise of the Creative Class ... and How it's Transforming Work, Leisure, Community and Everyday Life (Basic Books, New York)

Gemeente Rotterdam, 2007 Stadsvisie Rotterdam (Rotterdam Urban Vision), dienst Stedenbouw en Volkshuisvesting, Ontwikkelingsbedrijf Rotterdam (Housing and Urban Development, Rotterdam Development Corporation)

Glasgow City Council, 2005 Clyde Waterfront Regeneration Annual Report Glasgow City Council Glasgow City Council, 2008 Glasgow City Council Plan 2008-2011 Glasgow City Council

Glass R, 1964, "Introduction. Aspects of change", in London: Aspects of Change (MacGibbon and Kee, London) pp xiii - xlii

Glynn S, 2008, "Soft-selling gentrification?” Urban Research and Practice $1164-180$

Gutzon Larsen H, Lund Hansen A, 2008, "Gentrification gentle or traumatic? Urban renewal policies and socioeconomic transformations in Copenhagen" Urban Studies 45 2429-2448

Hackworth J, Smith N, 2001, "The changing state of gentrification" Tijdschrift voor Economische en Sociale Geografie $92464-477$

Harris A, 2008, "From London to Mumbai and back again: gentrification and public policy in comparative perspective" Urban Studies 452407 - 2428

Harvey D, 1989, "From managerialism to entrepreneurialism: the transformation of urban governance in late capitalism" Geografiska Annaler 71 3-17

Jager M, 1986, "Class definition and aesthetics of gentrification: Victoriana in Melbourne", in Gentrification and the City Eds N Smith, P Williams (Allen Unwin, Boston, MA) pp 78-91

Keating M, 1988 The City that Refused to Die, Glasgow: The Politics of Urban Regeneration (Aberdeen University Press, Aberdeen)

Kop van Zuid, 1995 Kop van Zuid (010 Rotterdam)

Kop van Zuid, 1999 Kop van Zuid 2 (010 Rotterdam)

Lambert C, Boddy M, 2002,"Transforming the city: post-recession gentrification and re-urbanisation", paper presented at the Conference on Upward Neighbourhood Trajectories: Gentrification in the New Century, 26-27 September, University of Glasgow; CNR paper 6, ESRC Centre for Neighbourhood Research, University of Bristol

Lees L, 2000, "A reappraisal of gentrification: towards a 'geography of gentrification'” Progress in Human Geography 24389 - 408

Lees L, 2003, "Policy (re)turns: gentrification research and urban policy - urban policy and gentrification research" Environment and Planning A 35571 - 574

Lees L, 2008, "Gentrification and social mixing: towards an inclusive urban renaissance?" Urban Studies 452449 - 2470

Lees L, Ley D, 2008, "Introduction to special issue on gentrification and public policy" Urban Studies $452379-2384$

Lees L, Slater T, Wyly E, 2008 Gentrification (Routledge, New York) 
Lehrer U, Laidley L, 2008, "Old mega-projects newly packaged? Waterfront redevelopment in Toronto" International Journal of Urban and Regional Research 32786 - 803

Loopmans M, 2008, "Relevance, gentrification and the development of a new hegemony on urban policies in Antwerp, Belgium" Urban Studies 422499 - 2519

McIntyre Z, 2008 Rebuilding Glasgow: Regeneration and Gentrification in a Post-industrial Context $\mathrm{PhD}$ dissertation, Department of Urban Studies, Glasgow University

MacLeod G, 2002, "From urban entrepreneurialism to a 'revanchist city'? On the social injustices of Glasgow's renaissance" Antipode 34 602-624

Marcuse P, 1986, "Abandonment, gentrification and displacement: the linkages in New York City", in Gentrification and the City Eds N Smith, P Williams (Unwin Hyman, London) pp 153-177

Mills C, 1988, "Life on the upslope': the postmodern landscape of gentrification" Environment and Planning D: Society and Space $6169-189$

Moulaert F, Rodriguez A, Swyngedouw E (Eds), 2003 The Globalized City: Economic Restructuring and Social Polarization in European Cities (Oxford University Press, Oxford)

Murphy L, 2008, "Third-wave gentrification in New Zealand: the case of Auckland" Urban Studies $452521-2540$

Slater T, 2004, "Municipally managed gentrification in south Parkdale, Toronto" The Canadian Geographer 48303 - 325

Slater T, 2006, "The eviction of critical perspectives from gentrification research" International Journal of Urban and Regional Research $30737-757$

Smith D, 2008, "The politics of studentification and '(un)balanced' urban populations: lessons for gentrification and sustainable communities?" Urban Studies 452541 - 2564

Smith D, Holt L, 2007, "Studentification and 'apprentice' gentrifiers within Britain's provincial towns and cities: extending the meaning of gentrification" Environment and Planning A 39 $142-161$

Smith N, 1979, "Towards a theory of gentrification: a back to the city movement of capital, not people" Journal of the American Planning Association 45538 - 548

Smith N, 1996 The New Urban Frontier: Gentrification and the Revanchist City (Routledge, New York)

Smith N, 2002, "New globalism, new urbanism: gentrification as a global urban strategy" Antipode $34427-450$

Spain D, 1993, "Been-heres versus come-heres" Journal of the American Planning Association 59 $156-172$

Swyngedouw E, Moulaert F, Rodriguez A, 2002, "Neoliberal urbanization in Europe: large-scale urban development projects and the new urban policy" Antipode $34432-577$

Tasan-Kok T, 2010, "Entrepreneurial governance: challenges of large-scale property-led urban regeneration projects" Tijdschrift voor Economische en Sociale Geografie 101126 - 149

Tiesdell S, 2009, "Glasgow: renaissance on the Clyde?", in Urban Design and the British Urban Renaissance Ed. J Punter (Routledge, London) pp 262-279

Uitermark J, 2003, “'Social mixing' and the management of disadvantaged neighbourhoods: the Dutch policy of urban restructuring revisited" Urban Studies 40531 - 549

Uitermark J, Duyvendak J, 2008, "Civilising the city: populism and revanchist urbanism in Rotterdam" Urban Studies 451485 - 1503

Uitermark J, Duyvendak J, Kleinhans R, 2007, "Gentrification as a governmental strategy: social control and social cohesion in Hoogvliet, Rotterdam" Environment and Planning A 39 125-141

van Criekingen M, Decroly J, 2003, "Revisiting the diversity of gentrification: neighbourhood renewal processes in Brussels and Montreal" Urban Studies 402451 - 2468

van Weesep J, 1994, "Gentrification as a research frontier" Progress in Human Geography 18 74-83

Vicario L, Martínez-Monje P M, 2003, "Another 'Guggenheim effect'? The generation of a potentially gentrifiable neighbourhood in Bilbao" Urban Studies $402380-2400$

Visser G, Kotze N, 2008, “The state and new-build gentrification in central Cape Town, South Africa" Urban Studies 452565 - 2593

Walks A, August M, 2008, "The factors inhibiting gentrification in areas with little non-market housing: policy lessons from the Toronto experience" Urban Studies 45 2594-2625

Warde A, 1991, "Gentrification as consumption: issues of class and gender" Environment and Planning D: Society and Space $9223-232$

Wyly E, Hammel D, 2008, “Commentary. Urban policy frontiers” Urban Studies 452643 - 2648 
Conditions of use. This article may be downloaded from the E\&P website for personal research by members of subscribing organisations. This PDF may not be placed on any website (or other online distribution system) without permission of the publisher. 